\title{
Outcome Analysis of Enders and Other Elastic Nails in Diaphyseal Fractures of Tibia
}

\author{
Swapnil Verman ${ }^{1}$, Narendra Saxena ${ }^{2}$, Sanjay Deshpande ${ }^{3}$ and Sohael M Khan ${ }^{4 *}$ \\ ${ }_{1}^{1}$ Junior Resident, Department of Orthopaedics, JNMC, India \\ ${ }^{2}$ Professor, Department of Orthopaedics, JNMC, India \\ ${ }^{3}$ Professor and Head, Department of Orthopaedics, JNMC, India \\ ${ }^{4}$ Assistant Professor and Consultant Spine Division, Department of Orthopaedics, JNMC, India
}

Submission: March 01, 2017; Published: March 09, 2017

*Corresponding author: Sohael M Khan, Assistant Professor and Consultant Spine Division, Department of Orthopaedics, JNMC, Wardha, India

\begin{abstract}
Background: Enders nailing is a good modality of treatment especially because of its cost effectiveness, minimum use of image intensifier and simple technique with short learning curve. Flexible or elastic nails are used in specified fracture situations in tibia. Our study aims to confirm that Ender nails are still useful and can give good results in patients of tibial diaphyseal fracture with proper indication. Concerning the low cost and simple technique we aimed to demonstrate that Ender nails may provide satisfactory results in selected group of diaphyseal fractures of tibia. The aim of the study was to find out the outcome analysis of Enders and other flexible nails in the diaphyseal tibia fractures.
\end{abstract}

Material and Methods: The present study was conducted in Department of Orthopaedics during the period of April 2015 to April 2016. This is a prospective and retrospective study. Post - operative the functional assessment was done and radiological evaluation was done.

Results: The study was conducted between April 2015 and April 2016, total 20 patients of tibialdiaphyseal fractures were treated with enders and other flexible nails. $90 \%$ of the patients in the study were males, $85 \%$ had injury from RTA. $40 \%$ of the patients had open clinical type of fracture and $60 \%$ had close clinical type of fracture.35\% of the patients with union time of $6-9$ weeks and $15 \%$ with $>17$ wks had full weight bearing 6 to 9 weeks, $5 \%$ of the patients with union time 6-9wks, and $>17$ wks had $10-13$ weeks. $50 \%$ of the patients had union time of 12-14 weeks, $25 \%$ had $15-17$ weeks, $10 \%$ had $18-20$ weeks and $10 \%$ had more than 20 weeks.

Conclusion: In can be concluded that Enders nail can be good alternative for treatment of diaphyseal fractures if proper patient selection is done pre - op and patients are explained regarding the same.

Keywords: Tibia; Fractures; Diaphysis; Enders; Outcome

\section{Introduction}

Tibial shaft fractures are important from several points of view. First, they are the most common fractures of long bones in the human body [1]. Second, the patient is often young and active and early return to daily activities necessary. Third, in tibial shaft fractures with massive bone and soft tissue injury the treatment can be difficult. In fact, except for the fractures due to low energy and with minimal displacement, surgical treatment is usually indicated for the rest.

Ender, an Austrian surgeon from the University of Vienna, first introduced Ender nails for fixation of peritrochanteric fractures in 1969 [2]. In the classic textbooks of orthopaedic surgery, Ender nails are advised in some specific conditions [3]. Since 1980, there have been several reports of successful use of Ender nails in tibial shaft fractures [4-14] . In recent years, the use of Ender nails in adult tibial shaft fractures significantly decreased in the USA and interlocking nailing has now replaced it as the preferred surgical technique.

The limitation is that plates cannot be usually used in open and comminuted fractures and though bridging plates can be used in a broader spectrum of fractures, an image intensifier is a must in for bridging plate fixation. Moreover, plating has limitations in communited fractures and compound fractures. External fixator is a treatment of choice in high-energy fractures and Gustilo Anderson type 2 \& 3 fractures. Unreamed intramedullary devices seem to be the alternative implant of choice for these fractures. The aim of the study was to find out the outcome analysis of Enders and other flexible nails in diaphyseal fractures of tibia. 


\section{Orthopedics and Rheumatology Open Access Journal}

\section{Method and Materials}

This was a prospective and retrospective study. This study was conducted in the Department of Orthopaedics, in a Tertiary care hospital. The aim of the study was to find out the outcome analysis of Enders and other flexible nails in diaphyseal fractures of tibia. The objective was to evaluate the healing and functional outcome after the surgical management of tibial fractures with enders nail and to evaluate the limitations of use of enders nailing, and to evaluate specific use of enders nailing in compound fractures and fractures near the end of the bones.

In each case a detailed history regarding the presenting complains along with personal history and mode of injury was taken. A detailed general examination along with a thorough local examination was done. The neighboring joints were also examined so that the other problems were not missed. Operative evaluation was done on the basis of functional assessment and radiological evaluation. Those patients fulfilling the inclusion criterion and giving a valid consent were subjected to operative procedure. This study included 20 patients with diaphyseal fractures of tibia.

\section{Observations and Results}

Between the period of April 2015 and April 2016, total 20 patients of tibial diaphyseal fractures were treated with enders and other flexible nails. $30 \%$ of the patients were in the age group of upto 18 years, $10 \%$ were in the age of $18-25$ years, $35 \%$ were in the age of $26-35$ years, $10 \%$ in $36-45$ years and $15 \%$ in the age group of more than 45 years. $90 \%$ of the patients in the study were males and remaining $10 \%$ were females. $15 \%$ of the patients had injury due to fall from height and $85 \%$ had injury from RTA. $45 \%$ of the patients had right side of injured leg an $55 \%$ had left side of injured leg. $5 \%$ of the patients had fracture shaft femur and $95 \%$ of them had no associated injuries.

Table 1: Distribution of patients according to onset of partial weight bearing.

\begin{tabular}{|c|c|c|c|}
\hline S. No. & $\begin{array}{c}\text { Onset of } \\
\text { partial weight } \\
\text { bearing }\end{array}$ & No. of & \\
\hline Cases & Percentage & & \\
\hline 1 & $5^{\text {th }}-10^{\text {th }}$ & 7 & 35 \\
\hline
\end{tabular}

\begin{tabular}{|c|c|c|c|}
\hline 2 & $11^{\text {th }}-15^{\text {th }}$ & 7 & 35 \\
\hline 3 & $16^{\text {th }}-20^{\text {th }}$ & 1 & 5 \\
\hline 4 & $21^{\text {st }}$ and above & 5 & 25 \\
\hline & Total & 20 & 100 \\
\hline
\end{tabular}

$40 \%$ of the patients had open clinical type of fracture and $60 \%$ had close clinical type of fracture. Hypertension was present in $20 \%$ of the patients and diabetes in $5 \%$ of the patients. $35 \%$ of the patients had fracture in mid shaft a $65 \%$ had in lower third. $5 \%$ of the patients had associated injuries and $95 \%$ need not have any type of associated injuries. $10 \%$ of the patients in closed and none in open type of clinical type of fracture had duration of injury 0 to 1 days, $45 \%$ of the patients with closed and $35 \%$ with open clinical type of fracture had duration of injury 2 to 3 days and $5 \%$ of the patients with closed and open type of clinical type of injury had duration of injury 4 to 5 days respectively (Table 1 ).

Each $35 \%$ of the patients had post operative days of 5 th10 th and 11 th-15th days of partial weight bearing, $5 \%$ had 16 th20 th and $25 \%$ of them had 21 st and above postoperative days of partial weight bearing (Figure 1).

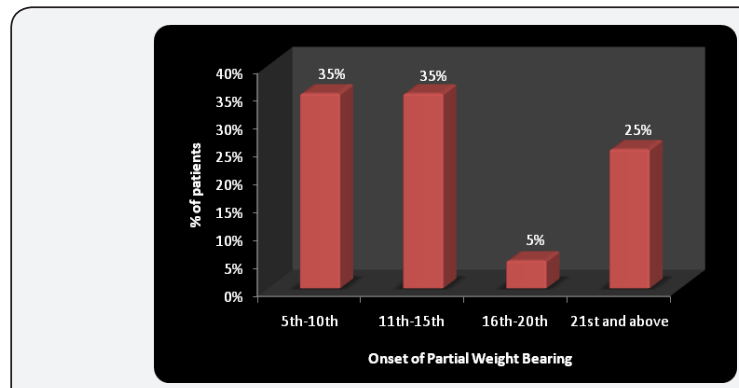

Figure 1: Distribution of patients according to onset of partial weight bearing.

$65 \%$ of the patients had onset of full weight bearing of 5 th -10 th week, $15 \%$ had 11 th- 15 th weeks and $10 \%$ had $16-20$ th weeks. $25 \%$ of the patients with union time of $12-14$ weeks and $5 \%$ with $>20$ weeks had partial weight bearing $5-10$ th day, $15 \%$ of the patients with union time $12-14$ weeks, $10 \%$ with $15-17$ weeks and $10 \%$ with $18-20$ weeks had $11-15$ th days. Statistically no significant association was found between partial weight bearing and union time (Figure 2) (Table 2).

Table 2: Relation between onset of full weight bearing and union time.

\begin{tabular}{|c|c|c|c|c|c|c|c|c|c|}
\hline \multirow{2}{*}{$\begin{array}{c}\text { Full } \\
\text { weight } \\
\text { bearing }\end{array}$} & \multirow{2}{*}{$\begin{array}{l}\text { No of } \\
\text { cases }\end{array}$} & \multicolumn{2}{|c|}{ 6-9 wks } & \multicolumn{2}{|c|}{ 10-13 wks } & \multicolumn{2}{|c|}{ 14-17 wks } & \multicolumn{2}{|c|}{$>17$ wks } \\
\hline & & $\mathbf{n}$ & $\%$ & $\mathbf{n}$ & $\%$ & $\mathbf{n}$ & $\%$ & $\mathbf{n}$ & $\%$ \\
\hline 6 to 9 wks & 13 & 7 & 35 & 3 & 15 & 2 & 10 & 1 & 5 \\
\hline $10-13 \mathrm{wks}$ & 2 & 1 & 5 & 0 & 0 & 0 & $\mathbf{0}$ & 1 & 5 \\
\hline $\begin{array}{l}14 \text { to } 17 \\
\text { wks }\end{array}$ & 2 & 0 & 0 & 2 & 10 & 0 & $\mathbf{0}$ & 0 & 0 \\
\hline$>17$ wks & 1 & 0 & 0 & 0 & 0 & 0 & $\mathbf{0}$ & 1 & 5 \\
\hline Total & 20 & 8 & 40 & 5 & 20 & 2 & 8 & 3 & 15 \\
\hline
\end{tabular}




\section{Orthopedics and Rheumatology Open Access Journal}

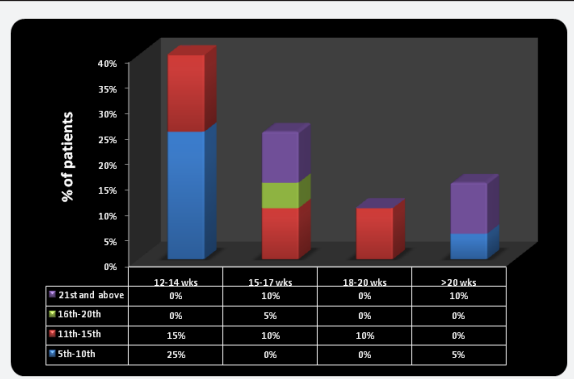

Figure 2: Relation between onset of partial weight bearing and union time.
$35 \%$ of the patients with union time of 6-9 weeks and $15 \%$ with $>17$ wks had full weight bearing 6 to 9 weeks, $5 \%$ of the patients with union time $6-9 \mathrm{wks}$, and $>17 \mathrm{wks}$ had $10-13$ weeks. Statistically no significant association was found between full weight bearing and union time.

$50 \%$ of the patients had union time of $12-14$ weeks, $25 \%$ had $15-17$ weeks, $10 \%$ had $18-20$ weeks and $10 \%$ had more than 20 weeks. One patient went in to non-union. There was a union rate of $95 \%$ in a mean period of 20 weeks. $20 \%$ of the patients had flexion range of movement $<100,5 \%$ had $111-120,30 \%$ had $121-130$ and $45 \%$ of them had $131-140$ respectively (Table 3 ).

Table 3: Relation between onset of partial weight bearing and union time.

\begin{tabular}{|c|c|c|c|c|c|c|c|c|c|}
\hline \multirow{2}{*}{$\begin{array}{c}\text { Partial } \\
\text { weight } \\
\text { bearing }\end{array}$} & \multirow{2}{*}{$\begin{array}{l}\text { No of } \\
\text { cases }\end{array}$} & \multicolumn{2}{|c|}{$12-14$ wks } & \multicolumn{2}{|c|}{$15-17$ wks } & \multicolumn{2}{|c|}{$18-20$ wks } & \multicolumn{2}{|c|}{$>20$ wks } \\
\hline & & $\mathrm{n}$ & $\%$ & $\mathrm{n}$ & $\%$ & $\mathrm{n}$ & $\%$ & $\mathrm{n}$ & $\%$ \\
\hline 5th-10th & 7 & 5 & 25 & 0 & 0 & 0 & $\mathbf{0}$ & 1 & 5 \\
\hline 11th-15th & 7 & 3 & 15 & 2 & 10 & 2 & 10 & 0 & $\mathbf{0}$ \\
\hline 16th-20th & 1 & 0 & 0 & 1 & 5 & 0 & 0 & 0 & o \\
\hline $\begin{array}{l}\text { 21st and } \\
\text { above }\end{array}$ & 5 & 0 & 0 & 2 & 10 & 0 & $\mathbf{0}$ & 2 & 10 \\
\hline Total & 20 & 8 & 40 & 5 & 20 & 2 & 8 & 3 & 15 \\
\hline
\end{tabular}

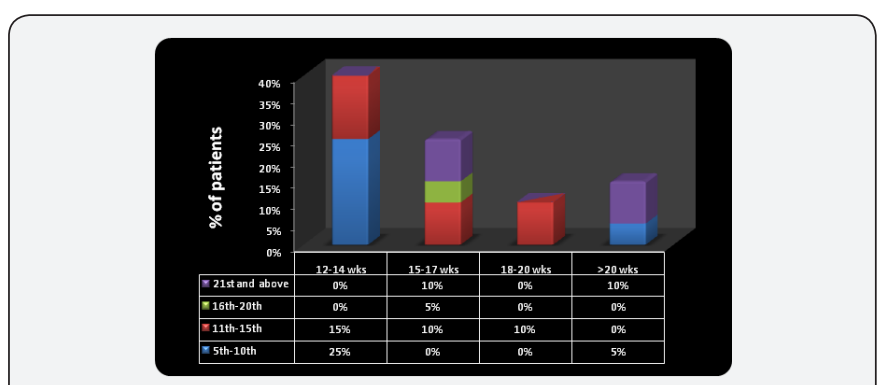

Figure 3: Relation between onset of partial weight bearing and union time.

$25 \%$ of the patients with union time of $12-14$ weeks and $5 \%$ with $>20$ wks had partial weight bearing $5-10^{\text {th }}$ day, $15 \%$ of the patients with union time $12-14$ wks, $10 \%$ with $15-17$ wks and $10 \%$ with $18-20$ weeks had $11-15^{\text {th }}$ days. Statistically no significant association was found between partial weight bearing and union time ( $\aleph 2$-value=15.66,p-value $=0.074$, Not Significant, $\mathrm{p}>0.05$ ) (Figure 3).

Table 4: Distribution of patients according to Time taken for union.

\begin{tabular}{|c|c|c|}
\hline $\begin{array}{c}\text { Union time in } \\
\text { weeks }\end{array}$ & No of patients & Percentage(\%) \\
\hline $12-14 \mathrm{wks}$ & 10 & 50 \\
\hline $15-17 \mathrm{wks}$ & 5 & 25 \\
\hline
\end{tabular}

\begin{tabular}{|c|c|c|}
\hline $18-20 \mathrm{wks}$ & 2 & 10 \\
\hline$>20 \mathrm{wks}$ & 2 & 10 \\
\hline Total & 20 & 95 \\
\hline
\end{tabular}

$35 \%$ of the patients with union time of 6-9 weeks and $15 \%$ with $>17$ wks had full weight bearing 6 to 9 weeks, $5 \%$ of the patients with union time 6-9 wks, and $>17$ wks had 10-13 weeks. Statistically no significant association was found between full weight bearing and union time $(\aleph 2$-value $=13.52$, $\mathrm{p}$-value $=0.140$, Not Significant, $\mathrm{p}>0.05$ ) (Figure 4) (Table 4).

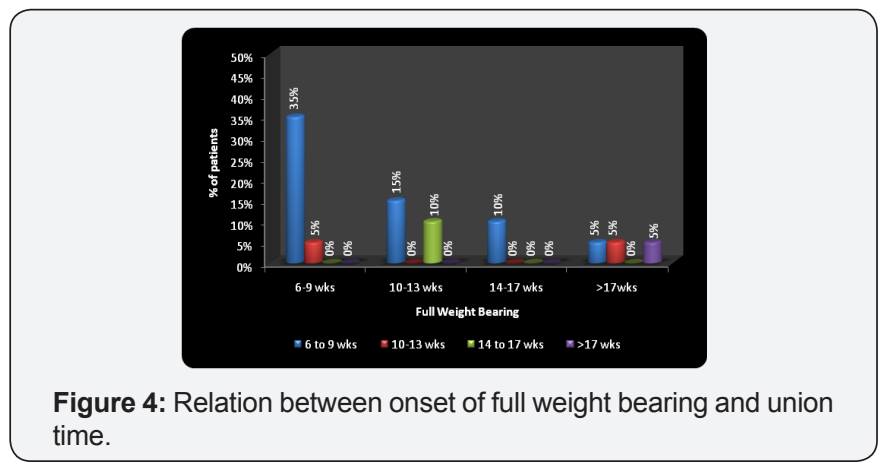

$50 \%$ of the patients had union time of $12-14$ weeks, $25 \%$ had $15-17$ weeks, $10 \%$ had $18-20$ weeks and $10 \%$ had more than 20 weeks. One patient went in to non-union. There was a union rate of $95 \%$ in a mean period of 20 weeks. 


\section{Radiological and Clinical Photograph}

CASE1 (Figures 5A-5C).

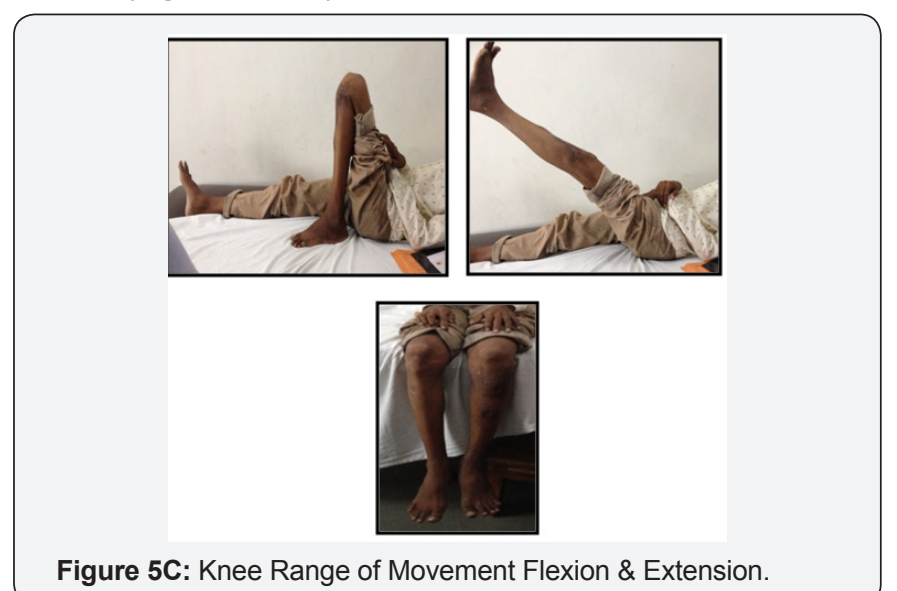

Discussion

There are several methods of treatment of fracture of shaft of tibia. Some people apply a groin-to-toe cast after closed reduction till clinical union occurs. This will lead to joint stiffness, muscle atrophy, osteoporosis, prolonged recumbency, and loss of working days. The popularly applied patellar tendon bearing cast (Sarmientio Tibial Plaster) and early weight bearing may not control alignment in all cases. Besides, there is chance of loss of reduction during treatment. Further, not all cases can be reduced to an acceptable position by closed methods. Sarmiento type patellar tendon bearing functional brace result an average shortening of $6.4 \mathrm{~mm}$, an average angulation of 8.0 and an average union lime of 5.7 months [15-17]. Recent trend is use of AO compression osteosynthesis. This has the advantage of perfect anatomic reduction and early movement of the affected limb, but need expertise. Complications following treatment with the AO - compression methods have been explained as due to insufficient experience (Thunold et al. 1975). Open reduction and internal fixation is not recommended for high energy compound fractures with gross soft tissue injury, comminution and there are chances of spreading infection [18].

A union rate of $95 \%$ in a mean period of 20 weeks is acceptable and comparable with previous reports summarized in (Table 1) and 29. This rate of union was achieved in spite of a significant number of high-energy trauma cases (i.e. $40 \%$ of the cases had open fractures). The time to union for both closed and open tibial fractures, as reported in the literature ranges from 15to 22 weeks In 1996, Chiu [19] compared the results of interlocking nails and Ender nails [6] Of 116 patients, 60 patients were randomly treated with interlocking nails and 56 with Ender nails. In the fractures with cortical comminution more than $50 \%$ of the diaphyseal diameter, the results of interlocking nails were significantly superior to those of Ender nails. Nevertheless, in the fractures with cortical comminution below 50\%, interlocking and Ender nails did not significantly differ [20].
In fact, the fractures with severe comminution are not good candidates for Ender nailing. Wiss $[13,14]$ in his comprehensive study on 111 cases stated that a minimum of $25 \%$ intact cortical circumference at the fracture site is required for a low complication rate. Four patients (20\%) were younger than 18 years. Ender nails can be used without growth plate damage and is an ideal option in children. Titanium elastic nails (TEN) for fixation of pediatric fractures are in many aspects similar to Ender nails, but has better stability of fracture after fixation.

The most common complication in our study was soft tissue irritation at the site of introduction and was seen in 7 patients. This is largely due to improper technique such as failure to bury the nail properly at the entry point.

In open fractures with major wounds, the problem is smaller. Another major point is that Ender nails, like interlocking nails are not effective tools for fixation of the fractures of the proximal third of tibia. Nail tends to exit from posterior cortex. There have been some reports of retrograde use of Ender nails (entrance near the ankle) [21].

Excessive bending of a nail may angulate the fracture site. The surgeon must allow enough bending for each fracture especially in highly comminuted fractures. However, complete straightening of nail can eliminate their 3-point fixation properties.

In highly comminuted cortex it is recommended to put the additional nail in such a manner that it comes in contact with the more comminuted cortex and provides better stability.

Use of external fixators has definite indications and their usefulness in compound fractures and as initial (temporary) stabilization cannot be ignored. There are two reports comparing the results of external fixator versus Ender nails $[22,23]$. In both studies which were performed on 2 groups of patients (one treated with external fixators and the other with Ender nails), there was no major difference in the result of one over the others. The complications of Ender nails were fewer in many aspects while the union rates were similar. In our study a mean healing occurred at 16 weeks.

In our study tibia united in an average of 16 weeks, which is comparable with the literature, where the tibia united in an average of 20 weeks. Merianos et al. [24] reported 31 fractures of tibial shaft treated with closed ender nailing and early weight bearing and all fractures united between 6 and 16 weeks and the average healing time was 15.2 weeks.

Mayer et al. [25] in 1985 reported a study of 49 patients treated with Ender Nail. They found a union rate of $96 \%$, a time to union of 24 weeks and an infection rate of 3.9\%. They concluded that Ender Nail could be the implant of choice especially for high-energy trauma with a massive soft tissue contusion.

Marianos et al. [24] also found good results in the treatment of 143 fractures of tibia with Ender Nails. They found a union 
rate of $98 \%$, a time to union of 5.4 months (23 week) and an infection rate lower than $2 \%$.

Zehtab [26] in 2004, studied 56 patients with diaphyseal tibial fractures and found excellent results with Ender Nail. He reported union rate of $98.2 \%$, time to union 4.7 months (19.8 weeks) and infection rate of $0 \%$. Time to union and union rate of tibial fractures treated with Ender nail are comparable with the results of interlocking nailing. Many authors have compared the treatment results of tibial fractures with Ender nails and interlocking nail and they have found not any statistically difference especially for stable types $[27,28]$. Chiu et al. [19] in 1996, presented a study of 116 patients with tibial fractures, 60 treated with interlocking nails and 56 with Ender nails. Their study found similar results in fractures with less than $50 \%$ of diaphyseal diameter comminution.

Soleimanpour et al. [29] found a union rate of $92.8 \%$ to $100 \%$ and a time to union from $4.2 \pm 1.4$ months for Ender Nails to $4.7 \pm 1.1$ months for interlocking nails. Sakaki et al. [30] studied 24 fractures treated with Ender nails and 20 with interlocking nail and reported similar results, too. They found union rates of $95.8 \%$ and a time to union of 20.8 weeks for Ender nail and $90 \%$ and 21.5 weeks for interlocking nail. Holbrook et al. [23] published a study comparing the results of Ender Nails and external fixator. They found that time to union for Ender Nails was 5.9 months to 6.6 months for external fixator. In fact, the fractures not stable of types $\mathrm{C}$ with severe comminution are not good candidates for Ender nailing.

Wiss [14] in his study of fifty two patients reported Fortyeight of the 52 fractures united in an average time of 16.8 weeks and there were no cases of deep infection or osteomyelitis. In 32 cases the fracture was closed and in the remaining 28 cases the fracture was open.

Similar results have been found by Huang et al. [20] and they have concluded that Ender nail is effective for the treatment

Table 5: Summaries of results in treatment of tibial fracture with Ender nails.

\begin{tabular}{|c|c|c|c|c|}
\hline Investigator & No of patient in study & $\begin{array}{l}\text { Percentage of open } \\
\text { fractures }\end{array}$ & Percentage of Union & Important points \\
\hline Hassenhuttl (1981) [6] & 235 & 75.8 & 92.9 & $\begin{array}{l}\text { Union rate is higher in } \\
\text { closed fractures, and } \\
\text { open fractures had more } \\
\text { complications }\end{array}$ \\
\hline $\begin{array}{l}\text { Pankovich et al. (1981) } \\
\text { [32] }\end{array}$ & 37 & 21.7 & 91.8 & \\
\hline Mayer et al. (1985) [8] & 51 & 49 & 96 & $\begin{array}{l}\text { Two malunions, two } \\
\text { infections }\end{array}$ \\
\hline Merlanos et al. (1985) [24] & 143 & 28 & 95 & Eight malunions \\
\hline Wiss (1986) [13] & 50 & 56 & 96 & \\
\hline Wiss et al. (1986) [14] & 111 & 50 & 94 & \\
\hline Rinaldi et al. (1987) [11] & 32 & $?$ & 98 & \\
\hline
\end{tabular}

of less comminuted unstable tibial shaft fractures, but should be used carefully for more comminuted unstable tibial shaft fractures.

Jahnke et al. [31] in their study with 80 patients concluded that intramedullary stabilization with Ender nails provides good control of unstable tibial shaft fractures. The use of pins with a smaller diameter ( 3.5 or $4 \mathrm{~mm}$ ) allows the surgeon to place more pins across the fracture site. The use of multiple pins and packing the intramedullary canal may provide better rotational stability.

Ando et al. [21] in their study with 280 fractures found that Ender nailing is an excellent semi conservative treatment for tibial shaft fractures, maintaining adequate elasticity at the fracture sites where much callus is formed, leading to a good union. The percentage of union was $97 \%$.

Hussain et al. [7] conducted a study of 39 fractures and emphasized that Ender nails provide effective fixation for the OTA stable class of tibial fractures and rotational and angular stability should be improved by a supplementary cast immobilization for fractures with unstable configuration and those located in the distal third of the diaphysis.

Considering the result of our study and in the literature we believe that Ender nailing, if performed correctly in properly selected patient, can be a very useful and effective method in fixation of tibial fractures with simple technique and minimum use of imaging [32-36].

As compared to implants such as interlocking nails, locking and other plates it is simple and cost effective. There are less chances of infection in closed fractures and better control of infection in compound fractures. This is additional advantage of Enders nail over the other implants, though we never deny the usefulness and good results of interlocking nails (Table 5). 


\section{Orthopedics and Rheumatology Open Access Journal}

\begin{tabular}{|c|c|c|c|c|}
\hline Jannke et al. (1992) [31] & 80 & 17 & 97.5 & $\begin{array}{c}\text { In type IIA open fractures, } \\
\text { nail is contraindicated } \\
\text { High complication rate } \\
\text { in type IIIB and IIIC open } \\
\text { fractures }\end{array}$ \\
\hline $\begin{array}{c}\text { Semenovicz et al. (1996) } \\
\text { [12] }\end{array}$ & 46 & 39 & 100 & One infection \\
\hline Ando et al. (2000) [21] & 280 & $?$ & 97 & \\
\hline \multicolumn{5}{|l|}{ Hussain et al. (2001) [7] } \\
\hline & 39 & 30 & 87 & \\
\hline RiemerB.L(1995) [34] & 88 & & 95.7 & \\
\hline $\begin{array}{l}\text { KeivanAhadi and Mir- } \\
\text { MostafaSadat(2004) [35] }\end{array}$ & 56 & & 98.2 & \\
\hline Our study & 20 & 8 & 95 & \\
\hline
\end{tabular}

\section{Summary and Conclusion}

The study of outcome analysis of enders and other flexible nails in diaphyseal fractures of tibia was carried out in the Department of Orthopaedics at Tertiary Centre consisting of 20 cases of fracture shaft of Tibia. In the light of results obtained it can be summarized and concluded that Enders nail can be good alternative for treatment of diaphyseal fractures of tibia in selected indications for following reasons, it's an effective modality which allows early ambulation and weight bearing, and decreased dependency. Infection is controlled effectively in compound fractures provided negative suction drain is used at window site. It reduces hospital stay of patients and later patient can return early to work, thus minimizes psychological trauma and financial burden to the patient. Satisfactory results in terms of union and functional recovery. It is cost effective. It is done by a simple technique can be mastered easily. Enders nailing is an excellent semi conservative treatment of tibial shaft fractures, maintaining adequate elasticity and micro mobility at the fracture site, which facilitate union when used in properly selected indications.

\section{References}

1. Leibson CL, Tosteson A, Gabriel Se, Ransom JE, Melton LJ (2002) Mortality, disability, and nursing home use for persons with hip fracture: a population based study. J Am Geriatr Soc 50(10): 16441650.

2. Anglen JO, Weinstein JN (2008) American Board of Orthopaedic Surgery Research Committee. Nail or plate fixation of intertrochanteric hip fractures: changing pattern of practice. A review of the American Board of Orthopaedic Surgery Database. J Bone Joint Surg Am 90(4): 700-707.

3. Forte ML, Virnig BA, Kane RL, Durham S, Bhandari M, et al. (2008) Geographic variation in device use for intertrochanteric hip fractures. ] Bone Joint Surg Am 90(4): 691-699.
4. Harris WH (1969) Traumatic arthritis of the hip after dislocation and acetabular fractures: treatment by mold arthroplasty. An end-result study using a new method of result evaluation. J Bone Joint Surg Am 51(4): 737-755.

5. Leung KS, So WS, Shen WY, Hui PW (1992) Gamma nails and dynamic hip screws for peritrochanteric fractures. A randomised prospective study in elderly patients. J Bone Joint Surg Br 74(3): 345-351.

6. Kyle RF, Gustilo RB, Premer RF (1979) Analysis of six hundred and twenty-two intertrochanteric hip fractures. J Bone Joint Surg Am 61(2): 216-221.

7. Clawson DK (1964) Trochanteric fractures treated by the sliding screw plate fixation method. J Trauma 4: 737-752.

8. Halder SC (1992) The Gamma nail for peritrochanteric fractures. J Bone Joint Surg Br 74(3): 340-344.

9. Boriani S, De Iure F, Bettelli G, Specchia L, Bungaro P, et al. (1994) The results of a multicenter Italian study on the use of the Gamma nail for the treatment of pertrochanteric and subtrochanteric fractures: a review of 1181 cases. Chir Organi Mov 79(2): 193-203.

10. Hardy DC, Descamps PY, Krallis P, Fabeck L, Smets P, et al. (1998) Use of an intramedullary hip-screw compared with a compression hip-screw with a plate for intertrochanteric femoral fractures. A prospective, randomized study of one hundred patients. J Bone Joint Surg Am 80(5): 618-630.

11. Aune AK, Ekeland A, Odegaard B, Grogaard B, Alho A (1994) Gamma nail vs. compression screw for trochanteric femoral fractures 15 reoperations in a prospective, randomized study of 378 patients. Acta Orthop Scand 65(2): 127-130.

12. Goldhagen PR, O'Connor DR, Schwarze D, Schwartz E (1994) A prospective comparative study of the compression hip screw and the gamma nail. J Orthop Trauma 8(5): 367-372.

13. Utrilla AL, Reig JS, Munoz FM, Tufanisco CB (2005) Trochanteric gamma nail and compression hip screw for trochanteric fractures: a randomized, prospective, comparative study in 210 elderly patients with a new design of the gamma nail. J Orthop Trauma 19(4): 229-233. 
This work is licensed under Creative Commons Attribution 4.0 License DOI:-10.19080/OROAJ.2017.05.555657

\section{Your next submission with Juniper Publishers will reach you the below assets}

- Quality Editorial service

- Swift Peer Review

- Reprints availability

- E-prints Service

- Manuscript Podcast for convenient understanding

- Global attainment for your research

- Manuscript accessibility in different formats

( Pdf, E-pub, Full Text, Audio)

- Unceasing customer service

Track the below URL for one-step submission https://juniperpublishers.com/online-submission.php 